\title{
Hvordan lykkes med etikkarbeidet?
}

Når helsepersonell møter etiske problemer i hverdagen, kan refleksjonsgrupper og -modeller være til god hjelp. Resultatet kan bli bedre tjenester for brukerne.

\section{FORFATTERE}

Morten Magelssen

forsker

Senter for medisinsk etikk, UiO

Heidi Marie Karlsen

forsker

Senter for medisinsk etikk, UiO

\section{Reidar Pedersen}

professor

Senter for medisinsk etikk, UiO

Lillian Lillemoen

forsker

Senter for medisinsk etikk, UiO

\section{NøKKELORD}

Etikk, Kommunehelsetjeneste, Veiledning

\section{HOVEDBUDSKAP}

Over halvparten av norske kommuner har fors $\varnothing$ kt etikktiltak i helse- og omsorgssektoren. Evalueringer viser at etikkarbeidet blant annet kan føre til økt etisk bevissthet og bedre løsninger på etiske utfordringer $\mathrm{i}$ arbeidshverdagen. Etikkarbeid er avhengig av gode rammevilkår for å lykkes.

De siste årene har over halvparten av norske kommuner startet etikkarbeid i helse- og omsorgstjenesten, de fleste gjennom det nasjonale etikkprosjektet «Samarbeid om etisk kompetanseheving» fra 2007 til 2015, der hele 243 kommuner deltok. Mange tusen etikkveiledere har blitt kurset, hvorav cirka halvparten var sykepleiere. Dette store fagutviklingsarbeidet er unikt både i nasjonal og internasjonal sammenheng.

Gjennom dette prosjektet ble etikkarbeid særlig igangsatt i sykehjem, hjemmetjenester og tilrettelagte boliger - ofte også i psykisk helsevern og rusomsorg. Skolehelsetjeneste, helsestasjoner og fastlegetjenester ble sjelden inkludert (1). 
pårørende, tvang, taushetsplikt og ressursbruk, og drøfting av etiske dilemmaer på arbeidsplassen (1-3).

\section{ETIKK I KOMMUNEN}

Kommunene som deltok i det nasjonale prosjektet, hadde frihet til å utforme etikkarbeidet lokalt uten sterke føringer sentralt. Det har medført at etikktiltakene varierer fra kommune til kommune, og ulike modeller har blitt prøvd ut. Ikke alt har fungert like godt, og hos cirka 40 prosent av kommunene har etikkarbeidet etter hvert blitt borte (4). Det vanligste tiltaket $\mathrm{i}$ kommunene har vært å etablere etikkrefleksjonsgrupper og utdanne etikkveiledere som leder drøftingene i disse gruppene.

Evalueringsforskning utført av Senter for medisinsk etikk med flere, har etter hvert gitt et ganske detaljert bilde av hva som har fungert godt, eller mindre godt. I denne artikkelen oppsummerer vi, basert på forskning fra Norge, først hva etikkarbeidet har ført til. Deretter gir vi et overblikk over hvilke former for etikkarbeid som har lyktes best, samt hvilke rammefaktorer som øker sjansen for å lykkes.

\section{ETIKKARBEIDET}

Over halvparten av etikkveilederne angir at etikkarbeidet har hatt stor betydning for tjenestene som ytes (4). Helsepersonellet stiller oftere spørsmål ved egen eller avdelingens praksis (5). De rapporterer om større bevissthet om etiske problemer i arbeidshverdagen (6).

Gjennom etikkrefleksjon slipper ansatte å stå alene med utfordringene, men kan dele dem med kolleger og finne frem til nye og bedre løsninger. Etikkarbeidet gir også økt kunnskap om etikk og juss (3).

Mange rapporterer at etikkrefleksjonen fører til større oppmerksomhet om brukerne og deres pårørende $(5,7)$. Brukermedvirkningen blir bedre, og sykehjemsansatte hevder at bruken av tvang har gått ned $(4,5)$. Mange forteller om større trygghet i yrkesut $\varnothing v e l s e n$ etter at en vanskelig situasjon har vært tatt opp i etikkrefleksjonen (3). I sum betyr dette at etikkarbeidet har påvirket kvaliteten på tjenestene (3).

\section{ARBEIDSMIL $\varnothing E T$}

Etikkrefleksjonen har også positiv innvirkning på arbeidsmiljøet (4). Ansatte blir tryggere på hverandre og snakker bedre sammen $(3,5,7)$. Det blir større åpenhet og $\varnothing$ kt toleranse for ulike oppfatninger. Dessuten blir det enklere å si ifra om problemer. En mulig forklaring er at etikkrefleksjonen skaper rom for kritikk, ulike synspunkter og virkelighetsforståelser. Samtidig blir det mulig for de ansatte å drøfte kritikk og ulikheter på en systematisk måte og finne gode felles løsninger på utfordringene.

\section{«Ansatte blir tryggere på hverandre og snakker bedre sammen.»}

Det er en svakhet for evalueringsforskningen at den bare har de involvertes egne utsagn å støtte seg til. Mer objektive kartlegginger av for eksempel arbeidsmiljø, tvangsbruk og 
tjenestekvalitet har ikke blitt utført. Men både ansatte, etikkveiledere og ledere på tvers av kommuner peker på de samme positive konsekvensene av etikkarbeidet. Fra forskning $\mathrm{i}$ spesialisthelsetjenesten vet vi at det samme gjelder for pasienter og pårørende (8).

\section{ETIKKREFLEKSJONSGRUPPER}

Selv om kommunene har satt i gang et stort mangfold av etikkaktiviteter, er det etikkrefleksjonsgrupper som har vært den klart vanligste arbeidsformen (1). Det er også etikkrefleksjonsgrupper som i størst grad blir videreført over tid. I tillegg hevder etikkveiledere og ansatte at det er denne arbeidsformen som inspirerer mest til positive endringer i praksis (1).

Etikkrefleksjonsgrupper arrangeres på arbeidsstedet og er vanligvis åpne for alle ansatte. Noen steder har de hatt faste grupper. Faste grupper kan gjøre at deltakerne opplever det som tryggere å dele egne opplevelser og synspunkter. Ulempen er at færre får mulighet til å delta.

Typisk varer gruppemøtet én time. 45 minutter blir anbefalt som minimum. For kontinuitetens skyld bør møtene arrangeres ukentlig eller annenhver uke, og ikke sjeldnere enn månedlig. Datoer og tider bør bestemmes god tid i forveien for å skape forutsigbarhet, og legges inn i avdelingens ukeplaner.

Mange steder har de hatt en fast dag og et fast tidspunkt. Gruppene fungerer best med fire til ti deltakere (7). Med færre deltakere blir arbeidet skjørt - med flere vil færre få komme til orde, og det kan føles mindre trygt å gripe ordet i gruppen.

Mange har også etikkrefleksjon på personalmøter eller rapportmøter, men problemet her er at det ikke blir mulig å gå tilstrekkelig i dybden på konkrete, etiske problemer fra arbeidshverdagen (9).

Hva finner sted i refleksjonsgruppene? Grovt sett kan vi dele det inn i

- refleksjon over konkrete utfordringer i arbeidshverdagen ved hjelp av refleksjonsmodeller,

- diskusjon av overordnete temaer ved hjelp av enkle diskusjonsmetoder, og/eller

- fri eller ustrukturert drøfting.

\section{REFLEKSJONSMODELLER}

Refleksjonsmodeller er stegvise fremgangsmåter som skal hjelpe med å belyse etiske dilemmaer. Senter for medisinsk etikk bruker en modell som består av seks spørsmål (SME-modellen, se faktaboks), og evalueringen viser at denne refleksjonsmodellen er mest utbredt (1). En viktig grunn til det er trolig at den er nokså enkel å bruke og inneholder elementer som mange blant helsepersonellet anser som viktige.

Slike modeller egner seg spesielt godt til å drøfte konkrete etiske problemer som de ansatte står overfor, enten knyttet til enkeltpasienter eller mer generelle problemer. Punktene følges ikke slavisk, men er til hjelp under diskusjonen for å sørge for at viktig informasjon om saken kommer frem (7). Systematikken bidrar til at flest mulig relevante momenter tas med $\mathrm{i}$ drøftingen, og dermed også til nye og velbegrunnete løsningsforslag (5). 
SME-modellen brukes til å drøfte etiske dilemmaer i helsetjenesten. Modellen omfatter seks punkter (10):

- Hva er det etiske problemet?

- Hva er fakta i saken?

- Hvem er berørte parter, og hva er deres syn og interesser?

- Hvilke verdier, prinsipper og lover er relevante?

- Hvilke handlingsalternativer finnes?

- Drøfting, konklusjon med begrunnelse for akseptable handlingsalternativer

\section{ENKLE DISKUSJONSMETODER}

En alternativ måte å stimulere til etikkrefleksjon i refleksjonsgruppene er det vi har kalt «enkle diskusjonsmetoder». Vanligste eksempler er «trafikklysmetoden», der røde, grønne og gule kort markerer hvorvidt du er uenig eller enig, eller er usikker på den foreslåtte løsningen på det etiske problemet, «fiskebollemetoden», en sekvensiell samtale der deltakerne skal respondere på forutgående talers poeng, eller etikkort, som beskriver ulike etiske problemstillinger.

Disse metodene er utviklet for å gi deltakerne etiske spørsmål, temaer eller verdiord, som for eksempel «respekt», som de ansatte kan diskutere. Men de benyttes også til å diskutere konkrete utfordringer. Fordelen med disse metodene er at de ikke krever mye forberedelse, og at de kan anses som mindre farlige fordi ingen må gå i detalj om egen praksis.

«En utfordring er at diskusjonen kan bli for generell.»

En utfordring er at diskusjonen kan bli for generell, og at den ikke koples tett nok til egen praksis (9). Dermed blir det mer usikkert om metodene fører til konkrete endringer i praksis. De enkle metodene fikk gjennomgående svakere evaluering, selv om også de har sine tilhengere som mener at metodene fungerer bra $(1,7,11)$. Noen etikkveiledere mente for eksempel at metodene kunne egne seg godt som et første møte med etikkrefleksjon for de ansatte fordi metodene er lettfattelige og stiller lave krav til deltakerne og etikkveilederne (9).

For å komme videre er det imidlertid viktig å gå over fra forhåndsdefinerte temaer og abstrakte verdier til å drøfte konkrete, selvopplevde etiske utfordringer (5). Vi anbefaler også å bruke en refleksjonsmodell fremfor å la diskusjonen være fri og ustrukturert.

\section{DELTAKERE I GRUPPEN}

Det har vist seg å være gunstigst når deltakerne i refleksjonsgruppen kommer fra samme arbeidssted, og gjerne samme avdeling. Det er en fordel at gruppene er tverrfaglige, fordi flere viktige perspektiver da kommer frem. Det er kun et fåtall steder der legene har deltatt $\mathrm{i}$ 
refleksjonsgruppene (1). Dette er uheldig, både for legenes del, som ikke blir med i viktig refleksjon, og for gruppediskusjonen, som går glipp av medisinske premisser som kan være avgjørende.

Kun unntaksvis har refleksjonsgruppene invitert med pasienter eller pårørende i diskusjonen av saker der de er berørte parter (1). Til vanlig er etikkrefleksjonsgruppene et forum for de ansatte selv, og trolig vurderer mange ansatte det som for krevende å skulle ha med øvrige parter i diskusjonen. Like fullt er det et ideal i etikken at alle involverte er representert i diskusjonen, og det er verdt å utforske videre hvordan pasient- og pårørendeperspektivene kan ivaretas i gruppene.

\section{ETIKKVEILEDEREN}

Etikkveilederen eller etikkfasilitatoren er personen som leder etikkrefleksjonsgruppen. Forskningen viser at vedkommende har en avgjørende rolle. Etikkveilederen leder gjerne gruppen på sitt eget arbeidssted, men det forekommer også at etikkveiledere kommer utenfra. Vedkommende må få opplæring i rollen.

Etikkveilederen må også være personlig egnet ved å ha tillit blant $\varnothing v r i g e$ ansatte, evne til å se en sak fra flere sider, motivasjon for oppgaven og mot til å ta ledelsen i gruppesamtalene. Det kan med fordel være to etikkveiledere på hver avdeling. Da kan de bistå hverandre i planleggingen og gjennomføringen, for eksempel ved at den ene tar notater fra drøftingen. Arbeidet er da også mindre sårbart hvis en etikkveileder skulle slutte.

\section{«Det kan med fordel være to etikkveiledere på hver avdeling.»}

Det varierer sterkt hvor mye opplæring og veiledning etikkveilederne får; bare snaut halvparten hadde fått veiledning (1). I våre studier uttrykker etikkveilederne gjennomgående et behov for mer kunnskap og veiledning, og mange føler seg litt utrygge i rollen $(4,9,11)$. Det aller viktigste for etikkveilederne er ferdigheter i å lede etikkrefleksjonsgruppene (12).

Veiledning og erfaringsutveksling i form av regelmessige nettverkssamlinger med andre etikkveiledere er til stor nytte. Kunnskap innen klinisk etikk, det vil si om de vanligste typene etiske problemer som oppstår i helsetjenesten, er også nyttig. Det samme er generell etikkunnskap, som setter helsepersonell i stand til å identifisere etiske problemer samt gir et språk til å sette ord på og diskutere etiske problemer.

Vi anbefaler at nye etikkveiledere får grundig opplæring i å veilede etikkrefleksjonsgrupper. Opplæringen bør gå over tid der gruppeprosesser blir observert og tilbakemelding gitt av mer erfarne kolleger. Noen steder, blant annet på NTNU Ålesund, VID vitenskapelige høgskole, Diakonhjemmet Oslo og Universitetet i Oslo, tilbys etterutdanningskurs eller mastergradsemner i veiledning av etikkrefleksjon.

\section{ANSATTES KUNNSKAP}

For at etikkarbeidet skal komme i gang og bli varig, må de ansatte se verdien i det og føle seg 
inkludert. Noen kommuner har funnet det nyttig med etikkurs for alle ansatte $f ø r$ etikkrefleksjonsgrupper har startet opp på avdelingene. Med slike kurs oppnådde de at ansatte ble mer bevisste på etiske utfordringer i egen arbeidshverdag. Dermed opplevde mange også et behov for etikkrefleksjon.

\section{LEDERENS NøKKELROLLE}

I de tilfellene der etikkarbeidet ikke har blitt varig, har grunnen ofte vært mangel på støtte fra ledere, eller at det ikke har vært avsatt nok tid (4). Avdelingslederen er den aller viktigste lederen. Hvis etikkrefleksjonen skal bli regelmessig, varig og betydningsfull for praksis, må lederen legge til rette for og motivere til slik refleksjon (11).

Etikkrefleksjonen må inn på avdelingens timeplan og gis tilstrekkelig tid. Arbeidsoppgavene må organiseres slik at flest mulig kan delta på møtene (12). Lederen bør formidle en tydelig forventning til de ansatte om at de deltar på etikkaktivitetene (7).

Lederen må også gi etikkveilederne de rammevilkårene de trenger, inkludert tid til oppgaven og anledning til kursing og veiledning. Avdelingslederen og etikkveilederen bør samarbeide om planlegging, organisering og gjennomføring av etikkarbeidet (12).

\section{ARBEIDET MÅ FORANKRES}

Etikkarbeidet bør også ha støtte - være forankret - hos kommunens $\emptyset$ verste ledelse. Da vil kommunen kunne forvente at etikkarbeid blir prioritert i de ulike virksomhetene, og vil kunne nedfelle dette kravet i planverk som forplikter enhetslederne. Det aller viktigste er forpliktelsen og engasjementet på avdelingsnivå.

Det finnes eksempler på virksomheter som har lyktes i å få til et levende etikkarbeid lokalt selv om de har møtt likegyldighet fra kommunal toppledelse. Men det motsatte er ikke tilfelle: Selv om kommunal ledelse går inn for etikkarbeid, vil manglende st $\varnothing t t e$ fra avdelingslederen i praksis gjøre det umulig å lykkes med dette arbeidet (5).

Det vi kan kalle «organisatorisk ustabilitet» er en viktig hemmer for etikkarbeidet. Ved mye sykefravær, lav bemanning, hyppig omorganisering og stort gjennomtrekk blant ansatte og ledere blir det vanskeligere å få etikkarbeidet til å overleve. Vi ser at etikkarbeidet ofte ikke er så robust som andre aktiviteter, og derfor lettere blir en salderingspost.

\section{KOMMUNENS ETIKKARBEID}

I mange kommuner har etikkarbeidet vært sårbart. Det har gjerne vært drevet frem av én eller noen få ildsjeler, og hvis disse har sluttet $\mathrm{i}$ jobben, har etikkarbeidet ofte gradvis tatt slutt. I andre kommuner har flere delt på ansvaret for etikksatsingen. Evalueringene viser tydelig behovet for robuste strukturer for kommunens etikkarbeid.

\section{«I noen kommuner, blant annet Halden, har de opprettet en etikkomité som en overordnet struktur for etikkarbeidet.»}


Kommunene har organisert arbeidet ulikt, men etter vår mening peker én modell seg ut som lovende: I noen kommuner, blant annet Halden, har de opprettet en etikkomité som en overordnet struktur for etikkarbeidet.

Komiteen har særlig to funksjoner: For det første fungerer den som en styringsgruppe for etikkarbeidet ved at den tar seg av kursing og veiledning av etikkveiledere på tjenestestedene. Den arrangerer også etikkundervisning for alle ansatte. For det andre drøfter komiteen klinisk-etiske saker fra tjenestene - inklusiv saker fra refleksjonsgruppene når sakene er spesielt kompliserte eller prinsipielt viktige.

\section{GIR BEDRE TJENESTER}

Det trengs mer systematisk evaluering av en slik organisering. Men denne modellen virker lovende ved at den ikke er så avhengig av en enkelt ildsjel, ved at det finnes et forum som vanskelige saker kan henvises til, og ved at den kan ivareta de lokale etikkveiledernes behov. Kliniske etikkomiteer er et etablert tilbud i alle helseforetak, men er foreløpig en ny struktur i kommunene. Per 2016 er det åtte etikkomiteer i kommunene (13).

Gjennom etikkrefleksjonen får ansatte og ledere anledning til å drøfte viktige utfordringer som de står i, i arbeidshverdagen. Når etikkarbeidet lykkes, fører det trolig til bedre tjenester for brukerne. Etikkarbeid er derfor en viktig del av kvalitetsarbeidet.

Med bakgrunn i forskning og erfaring har vi kunnet identifisere faktorer som fremmer eller hemmer utbyttet av etikkarbeidet. I tillegg til gjennomgangen i denne artikkelen vil vi henvise interesserte lesere til boken La etikken blomstre i praksis (7), som er fritt tilgjengelig for nedlastning, samt Senter for medisinsk etikks manual for kliniske etikkomiteer (10).

\section{REFERANSER}

1. Magelssen M, Gjerberg E, Pedersen R, Førde R, Lillemoen L. The Norwegian national project for ethics support in community health and care services. BMC Med Ethics 2016;17:70.

2. Gjerberg E, Førde R, Pedersen R, Bollig G. Ethical challenges in the provision of end-of-life care in Norwegian nursing homes. Social Science \& Medicine 2010;71(4):677-84.

3. Karlsen H, Gjerberg E, Magelssen M, Førde R, Pedersen R, Lillemoen L. Etikkarbeid i kommunal helse- og omsorgstjeneste - evaluering av etikkrefleksjonens innhold og betydning. Akseptert for publisering i Nordisk Sygeplejeforskning.

4. Magelssen M, Gjerberg E, Lillemoen L, Førde R, Pedersen R. Ethics support in community care makes a difference for practice. Nursing Ethics; 2016. Tilgjengelig fra: https://www.researchgate.net/publication/308532414_Ethics_support_in_community_care_makes_a_difference_for_practice (nedlastet 07.09.2017).

5. Lillemoen L, Pedersen R. Ethics reflection groups in community health services: an evaluation study. BMC Med Ethics 2015;16(1):25.

6. Söderhamn U, Kjostvedt HT, Sletteb $\varnothing \AA \AA$. Evaluation of ethical reflections in community healthcare: A mixed-methods study. Nursing Ethics 2014;22(2):194-204.

7. Børslett E, Heilmann G, Lillemoen L, Pedersen R. La etikken blomstre i praksis: en bok om systematisk refleksjon i arbeidshverdagen. Oslo: Universitetet i Oslo; 2011.

Tilgjengelig fra:

http://www.med.uio.no/helsam/tjenester/kunnskap/etikk-helsetjenesten/praksis/systematisk-etikkarbeid/etikkbok-refleksjon2011.pdf 
(nedlastet 28.09.2017).

8. Førde R, Linja T. «It scares me to know that we might not have been there!»: a qualitative study into the experiences of parents of seriously ill children participating in ethical case discussions. BMC Med Ethics 2015;16:40.

9. Tønnessen S, Lillemoen L, Gjerberg E. Refleksjonsgrupper i etikk: «Pusterom» eller læringsarena? Etikk i praksis 2016;10(1):1-16. Tilgjengelig fra: http://www.ntnu.no/ojs/index.php/etikk_i_praksis/article/view/1844/1977 (nedlastet 28.09.2017).

10. Paulsen JE, Pedersen R, Førde R. Manual for kliniske etikk-komiteer og etikk-ra?d i kommunehelsetjenesten. Oslo: Universitetet i Oslo, Senter for medisinsk etikk; 2011.

Tilgjengelig fra:

http://www.med.uio.no/helsam/tjenester/kunnskap/etikk-helsetjenesten/praksis/systematisk-etikkarbeid/manual-etikk-kommunehelsetjenesten 2011.pdf (nedlastet 28.09.2017).

11. Gjerberg E, Lillemoen L, Dreyer A, Pedersen R, Førde R. Etisk kompetanseheving i norske kommuner - hva er gjort, og hva har vært levedyktig over tid? Etikk i praksis 2014;8(2):31-49.

12. Lillemoen L, Pedersen R. Ethics in municipal health services: working systematically with, and developing competence in ethics. Clinical Ethics 2013;8(1):19-28.

13. Lillemoen L, Syse I, Pedersen R, Førde R. Er kliniske etikk-komiteer i den kommunale helse- og omsorgstjenesten bærekraftige? Etikk i praksis 2016;10(2):127-140. Tilgjengelig fra: http://www.ntnu.no/ojs/index.php/etikk_i_praksis/article/view/1939 (nedlastet 28.09.17). 